Article

\title{
Toxicology of Gambierdiscus spp. (Dinophyceae) from Tropical and Temperate Australian Waters
}

\author{
Michaela E. Larsson 1, ${ }^{*}$, Olivier F. Laczka ${ }^{1}$, D. Tim Harwood ${ }^{2}$, Richard J. Lewis ${ }^{3}$, \\ S. W. A. Himaya ${ }^{3}$, Shauna A. Murray ${ }^{1}$ and Martina A. Doblin ${ }^{1}$ \\ 1 Climate Change Cluster, University of Technology Sydney, P.O. Box 123 Broadway, Sydney, NSW 2007, \\ Australia; laczka.olivier@gmail.com (O.F.L.); shauna.murray@uts.edu.au (S.A.M.); \\ Martina.Doblin@uts.edu.au (M.A.D.) \\ 2 Cawthron Institute, 98 Halifax Street East, Private Bag 2, Nelson 7010, New Zealand; \\ Tim.Harwood@cawthron.org.nz \\ 3 Institute for Molecular Biosciences, The University of Queensland, Brisbane, QLD 4072, Australia; \\ r.lewis@imb.uq.edu.au (R.J.L.); h.siddhihalu@imb.uq.edu.au (S.W.A.H.) \\ * Correspondence: Michaela.Larsson@uts.edu.au; Tel.: +61-2-95148307
}

Received: 19 October 2017; Accepted: 15 December 2017; Published: 1 January 2018

\begin{abstract}
Ciguatera Fish Poisoning (CFP) is a human illness caused by the consumption of marine fish contaminated with ciguatoxins (CTX) and possibly maitotoxins (MTX), produced by species from the benthic dinoflagellate genus Gambierdiscus. Here, we describe the identity and toxicology of Gambierdiscus spp. isolated from the tropical and temperate waters of eastern Australia. Based on newly cultured strains, we found that four Gambierdiscus species were present at the tropical location, including G. carpenteri, G. lapillus and two others which were not genetically identical to other currently described species within the genus, and may represent new species. Only G. carpenteri was identified from the temperate location. Using LC-MS/MS analysis we did not find any characterized microalgal CTXs (P-CTX-3B, P-CTX-3C, P-CTX-4A and P-CTX-4B) or MTX-1; however, putative maitotoxin-3 (MTX-3) was detected in all species except for the temperate population of G. carpenteri. Using the $\mathrm{Ca}^{2+}$ influx SH-SY5Y cell Fluorescent Imaging Plate Reader (FLIPR) bioassay we found CTX-like activity in extracts of the unidentified Gambierdiscus strains and trace level activity in strains of G. lapillus. While no detectable CTX-like activity was observed in tropical or temperate strains of G. carpenteri, all species showed strong maitotoxin-like activity. This study, which represents the most comprehensive analyses of the toxicology of Gambierdiscus strains isolated from Australia to date, suggests that CFP in this region may be caused by currently undescribed ciguatoxins and maitotoxins.
\end{abstract}

Keywords: Benthic Harmful Algal Bloom (BHAB); Ciguatera Fish Poisoning (CFP); Ciguatoxin (CTX); Fluorescent Imaging Plate Reader (FLIPR); Liquid Chromatography-Tandem Mass Spectrometry (LC-MS/MS); Maitotoxin (MTX)

\section{Introduction}

Ciguatera Fish Poisoning (CFP) is a human illness which arises from the consumption of marine fish contaminated with ciguatoxins (CTX) [1]. Globally, it is estimated that between 50,000 and 200,000 people each year are affected [2], making it the most prevalent nonbacterial human illness associated with seafood consumption [3,4]. The risk of CFP is higher in tropical locations and is particularly prevalent among island communities who rely on seafood for survival [5,6], affecting up to 2000 per 100,000 people each year [7]. However, with the onset of international travel and worldwide seafood trade, this foodborne syndrome has now become a global issue [8-10].

Some species of dinoflagellates from the genus Gambierdiscus produce CTXs, the causative agents of CFP [11]. Adachi and Fukuyo [12] originally described Gambierdiscus toxicus, the first species in the 
genus, from samples collected in the Gambier Islands, French Polynesia. For many years, the genus was thought to be monotypic; however, increased interest and the application of molecular techniques toward identification procedures has led to its reclassification into at least 15 Gambierdiscus species and five sub-groups [13-16]. Targeted sampling and continued research will likely reveal more diversity in the future. The identification of Gambierdiscus species based on thecal plate morphology is very challenging, as the differences between species are subtle and largely overlap [12,17-19]. Assessment of the phylogenetic relationships of species based on particular genetic markers constitutes additional information for species identification [13,19]. Phylogenetic analysis of Gambierdiscus is primarily inferred from the nuclear-encoded ribosomal RNA gene (rDNA), including multiple regions of the large subunit (LSU D1-D3 and LSU D8-D10) [13,19], the small subunit (SSU) or the internal transcribed spacer (ITS) [13].

CTXs are highly potent, lipophilic, polyether toxins which affect mammalian cells by activating voltage gated sodium channels [20-22]. Different structural forms of CTXs can be produced by Gambierdiscus species (e.g., P-CTX-3B, P-CTX-3C, P-CTX-4A, P-CTX-4B), each displaying differing toxicities [23]. Furthermore, CTXs isolated from marine fish are different from those produced by Gambierdiscus species [24,25] and can differ between locations (e.g., Atlantic Ocean vs. Pacific Ocean) [26-29]. Maitotoxins (MTXs) are also produced by species of Gambierdiscus [30]. These large, potent polyether toxins enhance intracellular calcium levels [31-33] and are amongst the most lethal non-proteinaceous natural compounds known [34].

Routine monitoring of toxins (particularly CTXs) produced by Gambierdiscus species is complicated by the many structural differences in the natural products produced, typically low observable quantities, and the lack of adequate reference standards [1]. Currently, there is, no validated unified approach for evaluating the toxicity of Gambierdiscus strains. Traditionally, the most common assessment of Gambierdiscus toxicity was via the mouse bioassay [19,23]. This involves administering the extracted toxin intraperitoneally or orally to Swiss albino mice, observing the symptomatology and calculating the median lethal dose $\left(\mathrm{LD}_{50}\right)$ [35]. This method however is non-specific and does not allow identification of the compound responsible for the observed toxicity. More recently, mammalian cell-based assays have been developed which assess the toxicity of a microalgal extract and provide a degree of differentiation amongst toxin classes. These include neuroblastoma (neuro-2a) cytotoxicity [36]; human erythrocyte lysis [37] and the $\mathrm{Ca}^{2+}$ influx SH-SY5Y cell Fluorescent Imaging Plate Reader (FLIPR) bioassay [38]. Liquid Chromatography-Tandem Mass Spectrometry (LC-MS/MS) is another analytical technique that provides the most specific evaluation of toxins but is limited by the number of forms for which standards are available. This method can detect microalgal-derived characterized toxins such as P-CTX-3B, P-CTX-3C, P-CTX4A, P-CTX4B, MTX-1 and putative MTX-3 [39-41].

There have been large outbreaks of CFP in Australia, with two human fatalities and more than 1400 documented cases between 1965 and 2010 [42,43]. Outbreaks primarily occurred in Queensland $[42,44,45]$ and the Northern Territory [46], with one case from Victoria traced back to the consumption of a Maori wrasse (Cheilinus undulates) imported from the Great Barrier Reef [46]. More recently, there have been multiple cases of ciguatera in northern New South Wales, linked with the consumption of locally caught Spanish mackerel (Scomberomorus commerson) contaminated with P-CTX-1B [47].

Within Australia, the presence of Gambierdiscus has been documented throughout the Great Barrier Reef, Queensland [48-52], at Exmouth in Western Australia [53] and at several sites in temperate locations in New South Wales [54]. However, complete identification of the species and toxicology analyses were not included in these studies. Work to characterize the diversity within Australia is underway, with G. carpenteri and a species much like G. belizeanus described at several locations in the Great Barrier Reef $[55,56]$, as well as G. carpenteri being documented at Merimbula and Wapengo Lagoon, New South Wales [57]. Interestingly, the species of Gambierdiscus found in Exmouth, Western Australia was similar to G. carpenteri [53], suggesting this species is well adapted to Australian 
conditions and may be widely distributed. More recently, G. lapillus was described from samples collected at Heron Island [58] and a previously unidentified strain of Gambierdiscus from the same location [15] was reclassified as a new species, G. honu [40]. Although our understanding of the identity of Gambierdiscus species in Australia is advancing, very little is known about their toxicology (Table 1).

Table 1. Toxicology of Gambierdiscus species documented from the Australian region. NA denotes information is not available.

\begin{tabular}{ccccc}
\hline Species & \multicolumn{1}{c}{ Location } & Toxicity & LC-MS/MS Profile & Reference \\
\hline G. cf. belizeanus & Heron Island, Queensland & NA & NA & {$[55]$} \\
\hline \multirow{2}{*}{ G. carpenteri } & Townsville, Queensland & NA & NA & {$[55,56]$} \\
\cline { 2 - 5 } & $\begin{array}{c}\text { Merimbula and Wapengo } \\
\text { Lagoon, New South Wales }\end{array}$ & NA & $\begin{array}{c}\text { No CTX-3B, -3C, -4A, -4B } \\
\text { No MTX-1, or MTX-3 }\end{array}$ & {$[57]$} \\
\hline G. honu & Heron Island, Queensland & NA & NA & {$[15,40]$} \\
\hline G. lapillus & Heron Island, Queensland & NA & $\begin{array}{c}\text { No CTX-3B, -3C, -4A, -4B } \\
\text { No MTX-1 } \\
\text { MTX-3 present }\end{array}$ & {$[58]$} \\
\hline G. toxicus * & $\begin{array}{c}\text { Arlington Reef, Queensland } \\
\text { Platypus Bay, Queensland }\end{array}$ & Positive & NA & {$[49]$} \\
\hline
\end{tabular}

* The identification of G. toxicus is not certain as the study occurred prior to revision of the genus.

In this study, single cells of Gambierdiscus from tropical and temperate Australia were isolated, and monoclonal cultures established. To verify their identity to species level, DNA was extracted from cultures and the D1-D3 and D8-D10 regions of the large subunit ribosomal RNA gene were sequenced. Toxicity was assessed using LC-MS/MS and the $\mathrm{Ca}^{2+}$ influx SH-SY5Y cell FLIPR bioassay, advancing our understanding of the organisms which contribute to CFP in Australia.

\section{Results}

\subsection{Strain Identification}

Maximum Likelihood and Bayesian analyses of the LSU rDNA D1-D3 and D8-D10 regions provided evidence to support the clades described in Nishimura et al. [59] for Gambierdiscus species. All five temperate strains of Gambierdiscus (UTSMER9A3, UTSMER8B4, UTSMER7A1, UTSMER1A3, UTSMER8A4) and four tropical strains (UTSHI2C4, UTSHI6C3, UTSHI6A1, UTSHI6D2), group with other strains of G. carpenteri in both phylogenies with high support (Figure 1a,b). Therefore, most of the isolates collected from eastern Australia were identified as G. carpenteri (Table 2). Three strains (UTSHI6B5, UTSHI2B6, UTSHI2B5) group with high support in the LSU rDNA D8-D10 region phylogeny with G. lapillus (Figure 1b), a new species described from the same tropical location in eastern Australia (Heron Island) [58]. Sequences were not available however, to compare the LSU rDNA D1-D3 region phylogeny. Strain UTSHI6A6 groups within clade V, the most diverse Gambierdiscus clade [59], in both LSU gene phylogenies. This strain is closely related to, but distinct from, G. pacificus strains from around the world (Figure 1a,b). Similarly, strain UTSHI6B1 groups within clade III [59] and is closely related to G. silvae in both phylogenies, but also forms a distinct cluster (Figure 1a,b). More analyses are required to fully describe these strains and both are therefore referred to as Gambierdiscus sp. in this study. 
a)

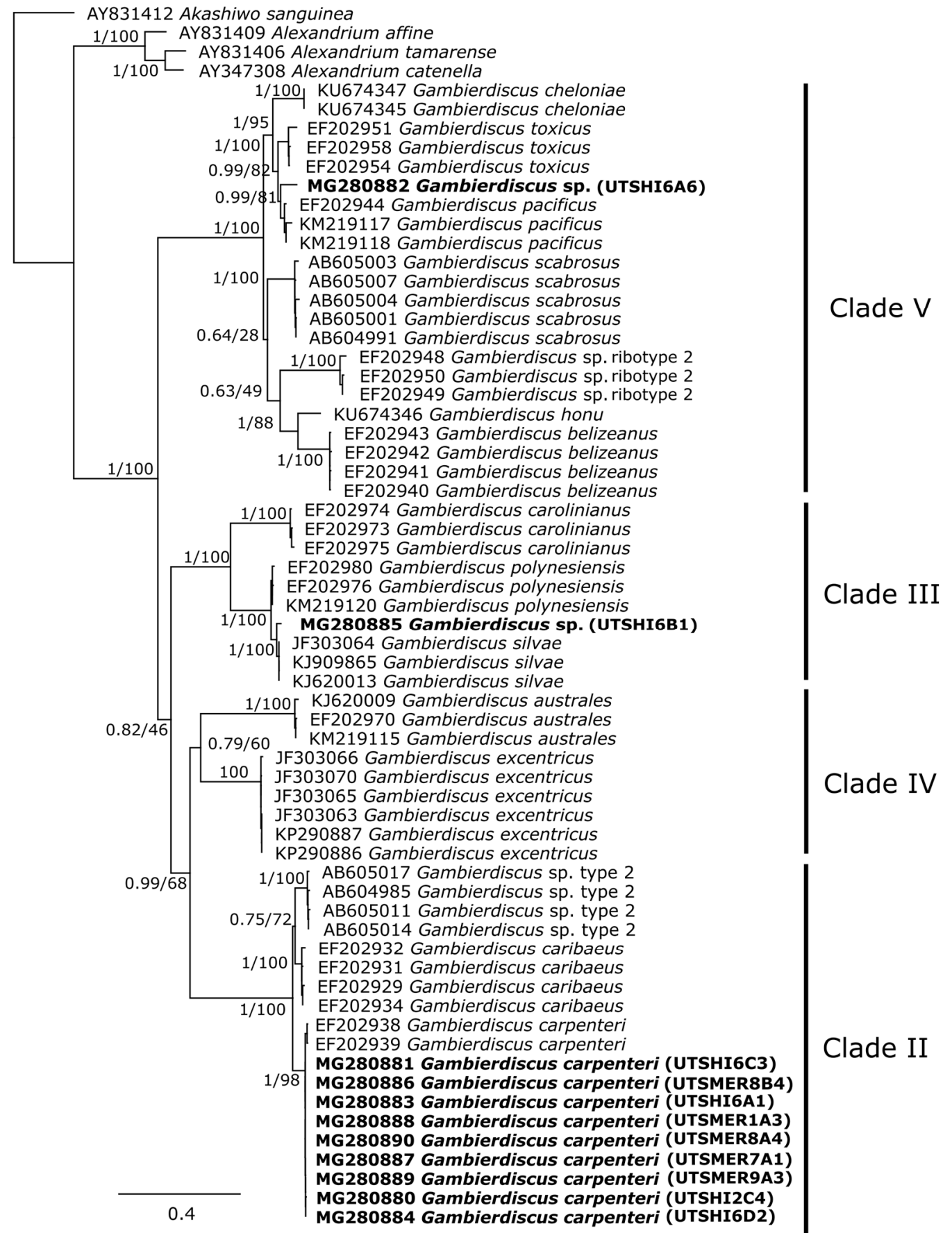

Figure 1. Cont. 
b) AY831411 Akashiwo sanguinea

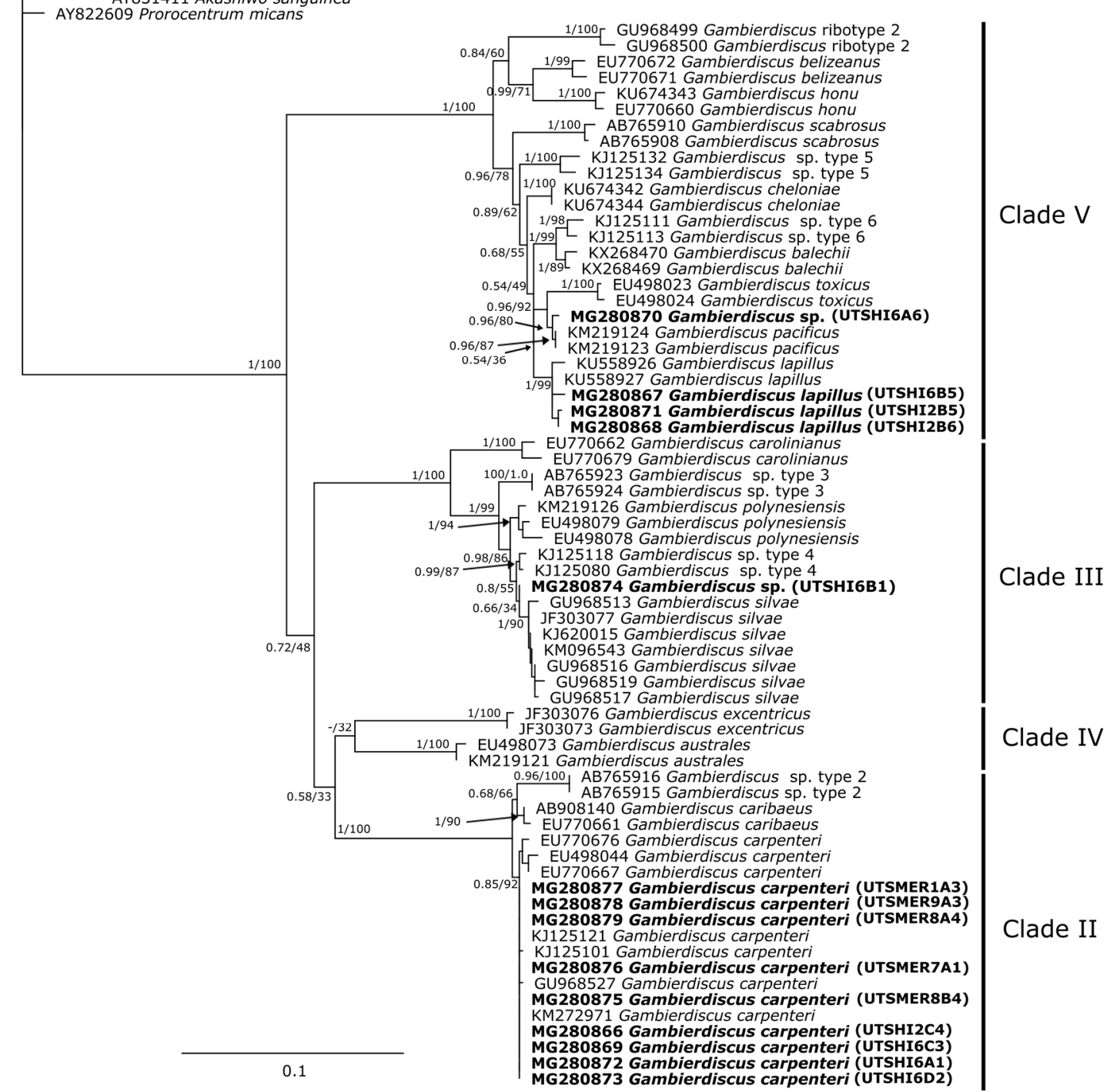

Figure 1. Maximum Likelihood phylogenetic tree showing alignment of the D1-D3 region (a) and the D8-D10 region (b) of the large subunit (LSU) rDNA sequences. Strains from this study are shown in bold. Values at nodes represent Bayesian posterior probability and Maximum Likelihood bootstrap support. 
Table 2. Geographic origin and toxicity of Gambierdiscus strains established in this study. All strains were grown at $24^{\circ} \mathrm{C}$ for toxin analysis. Strains listed with temperatures (e.g., $18^{\circ} \mathrm{C}$ and $27^{\circ} \mathrm{C}$ ), indicate additional growth temperatures that were tested. For the LC-MS/MS analysis, ND denotes toxins not detected. For the $\mathrm{Ca}^{2+}$ influx SH-SY5Y cell FLIPR bioassay, results are shown as the number of CTX- and MTX-like peaks of activity and NA signifies strains which were not analysed.

\begin{tabular}{|c|c|c|c|c|c|c|c|c|}
\hline \multirow{2}{*}{ Species Name } & \multirow{2}{*}{ Site of Isolation } & \multirow{2}{*}{ Strain Number } & \multicolumn{2}{|c|}{ Genbank Accession No. } & \multicolumn{2}{|c|}{ LC-MS/MS } & \multicolumn{2}{|c|}{$\begin{array}{l}\mathrm{Ca}^{2+} \text { Influx SH-SY5Y } \\
\text { Cell FLIPR Bioassay }\end{array}$} \\
\hline & & & LSU D1-D3 & LSU D8-D10 & CTX & MTX & $\begin{array}{l}\text { CTX-Like } \\
\text { Activity }\end{array}$ & $\begin{array}{c}\text { MTX-Like } \\
\text { Activity }\end{array}$ \\
\hline Tropical G. carpenteri & \multirow{3}{*}{ Heron Island Lagoon, Australia } & \multirow{3}{*}{ UTSHI2C4 } & \multirow{3}{*}{ MG280880 } & \multirow{3}{*}{ MG280866 } & ND & MTX-3 & 0 & 3 \\
\hline Tropical G. carpenteri $\left(18{ }^{\circ} \mathrm{C}\right)$ & & & & & ND & MTX-3 & NA & NA \\
\hline Tropical G. carpenteri $\left(27^{\circ} \mathrm{C}\right)$ & & & & & ND & MTX-3 & NA & NA \\
\hline Tropical G. carpenteri & Heron Island Lagoon, Australia & UTSHI6C3 & MG280881 & MG280869 & ND & MTX-3 & 0 & 4 \\
\hline Tropical G. carpenteri & Heron Island Lagoon, Australia & UTSHI6A1 & MG280883 & MG280872 & ND & MTX-3 & NA & NA \\
\hline Tropical G. carpenteri & Heron Island Lagoon, Australia & UTSHI6D2 & MG280884 & MG280873 & ND & MTX-3 & NA & NA \\
\hline Temperate G. carpenteri & \multirow{3}{*}{ Merimbula Inlet, Australia } & \multirow{3}{*}{ UTSMER9A3 } & \multirow{3}{*}{ MG280889 } & \multirow{3}{*}{ MG280878 } & ND & ND & 0 & 4 \\
\hline Temperate G. carpenteri $\left(18^{\circ} \mathrm{C}\right)$ & & & & & ND & ND & NA & NA \\
\hline Temperate G. carpenteri $\left(27^{\circ} \mathrm{C}\right)$ & & & & & ND & ND & NA & NA \\
\hline Temperate G. carpenteri & Merimbula Inlet, Australia & UTSMER8B4 & MG280886 & MG280875 & ND & ND & 0 & 4 \\
\hline Temperate G. carpenteri & Merimbula Inlet, Australia & UTSMER7A1 & MG280887 & MG280876 & ND & ND & NA & NA \\
\hline Temperate G. carpenteri & Merimbula Inlet, Australia & UTSMER1A3 & MG280888 & MG280877 & ND & ND & NA & NA \\
\hline Temperate G. carpenteri & Merimbula Inlet, Australia & UTSMER8A4 & MG280890 & MG280879 & ND & ND & NA & NA \\
\hline G. lapillus & Heron Island Lagoon, Australia & UTSHI6B5 & & MG280867 & ND & MTX-3 & 1 & 3 \\
\hline G. lapillus & Heron Island Lagoon, Australia & UTSHI2B6 & & MG280868 & ND & MTX-3 & 1 & 2 \\
\hline G. lapillus & Heron Island Lagoon, Australia & UTSHI2B5 & & MG280871 & ND & MTX-3 & NA & NA \\
\hline Gambierdiscus sp. & Heron Island Lagoon, Australia & UTSHI6A6 & MG280882 & MG280870 & ND & MTX-3 & 1 & 2 \\
\hline Gambierdiscus sp. & Heron Island Lagoon, Australia & UTSHI6B1 & MG280885 & MG280874 & ND & MTX-3 & 1 & 3 \\
\hline
\end{tabular}




\subsection{Detection of Characterized Ciguatoxins (CTXs) and Maitotoxins (MTXs)}

Analysis of the Gambierdiscus culture extracts using LC-MS/MS did not reveal the presence of the microalgal-derived ciguatoxins P-CTX-3B, P-CTX-3C, P-CTX-4A and P-CTX-4B (for which we had calibration standards), or MTX-1, in any of the strains isolated in this study. Putative MTX-3 was detected in all tropical strains of Gambierdiscus including G. carpenteri, but was absent from all temperate strains of the same species (Table 2). These toxin profiles did not change when the cultures were grown at 18 or $27^{\circ} \mathrm{C}$ (Table 2). Tropical strains of G. carpenteri produced MTX-3 at temperatures as low as $18{ }^{\circ} \mathrm{C}$ and at $27^{\circ} \mathrm{C}$ and the temperate cultures did not produce MTX-3 at either temperature.

\subsection{Presence of Ciguatoxin (CTX) and Maitotoxin-Like (MTX) Activities in Isolated Strains}

The $\mathrm{Ca}^{2+}$ influx SH-SY5Y cell FLIPR bioassay [38] showed distinct CTX-like activities (i.e., post veratridine addition) in several of the High Performance Liquid Chromatography (HPLC) fractions from the dichloromethane phase of three of the four Gambierdiscus species. Two strains, Gambierdiscus sp. (UTSHI6A6) and Gambierdiscus sp. (UTSHI6B1), showed clear CTX-like activities (Figure 2g,h, Table 2) and low levels of CTX-like activity were also detected in both strains of G. lapillus (Figure 2e,f). No distinct CTX-like activity was detected for tropical or temperate strains of G. carpenteri (Figure 2a-d). MTX-like activity was detected in fractions eluted at 42-45 $\mathrm{min}$ in extracts of all species except UTSMER9A3, one of the temperate strains of G. carpenteri (Figure 2d). CTX-like activity was also detected in the fractions eluted prior to, during and following this MTX-like activity peak (Figure 2).
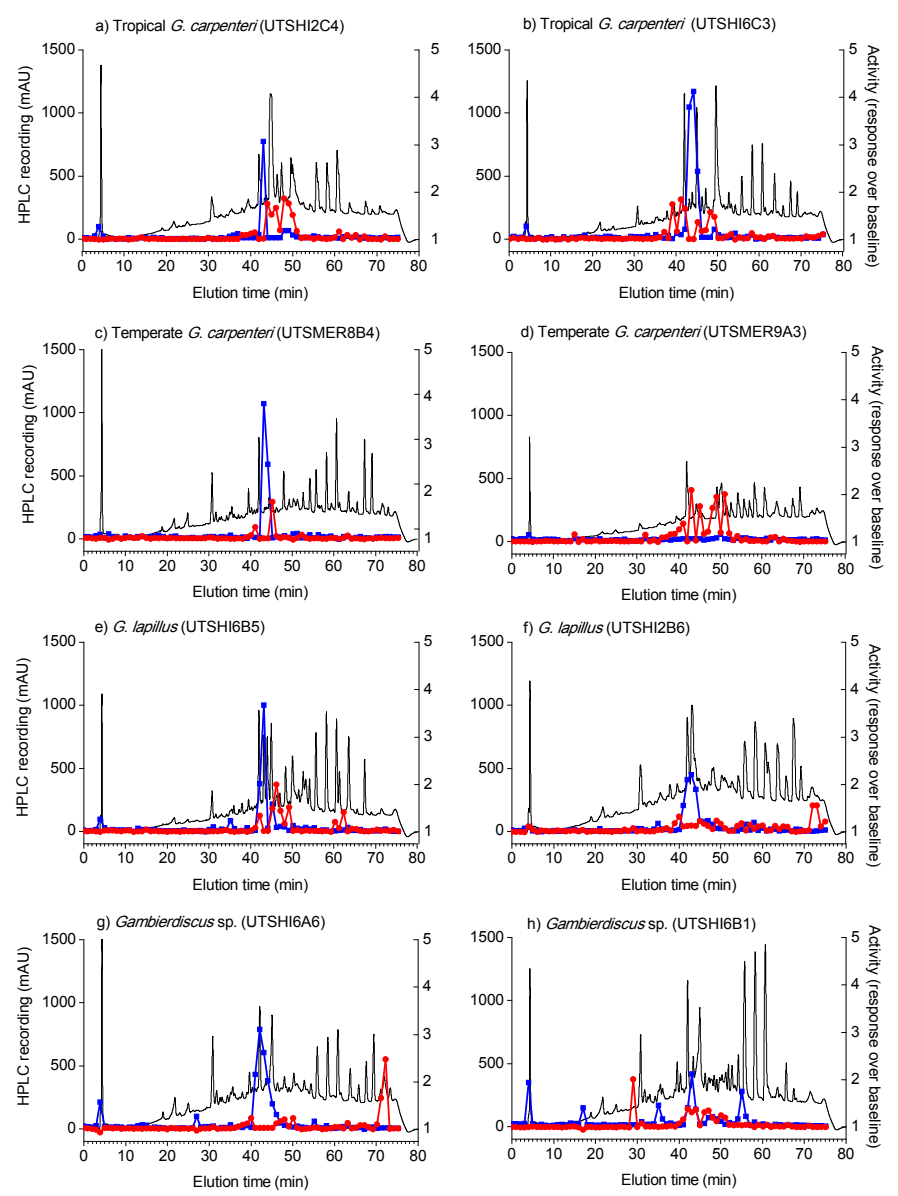

Figure 2. Ciguatoxin-like (red) and maitotoxin-like (blue) activities of the High Performance Liquid Chromatography (HPLC) fractionated (black trace) dichloromethane phase of extracts from Gambierdiscus strains isolated in this study. 
In comparison to the variable CTX-like activities amongst strains, strong MTX-like activities were detected in all Gambierdiscus strains tested. There was a distinct peak in the earliest fractions of the HPLC-fractionated methanol phase and large activity in the fractions eluted between 30 and $60 \mathrm{~min}$ for all extracts (Figure 3). All the strains of G. carpenteri from both tropical and temperate Australia showed additional MTX-like activity peaks (Table 2) in fractions eluted between 10 and 30 min (Figure 3). CTX-like activity was also detected in most extracts, prior to and following strong MTX-like activity (Figure 3).
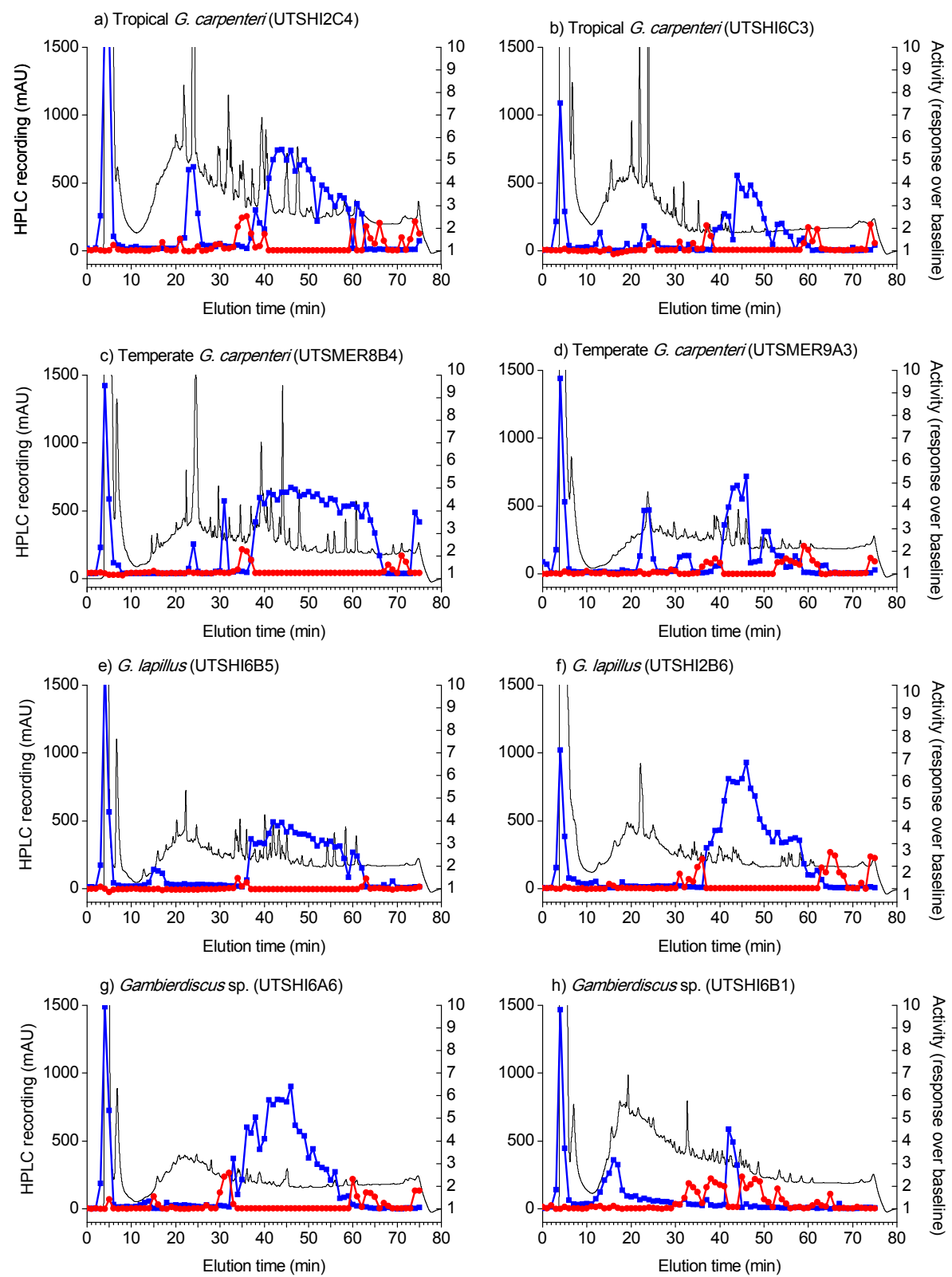

Figure 3. Ciguatoxin-like (red) and maitotoxin-like (blue) activities of the HPLC fractionated (black trace) methanol phase of extracts from Gambierdiscus strains isolated in this study.

\section{Discussion}

CFP has been an issue in Australia for some time but very little is known about the toxicology of the causative organism/s in this region. Prior to this study, strains from various Australian sites had been identified but a thorough analysis of their toxicology had not been undertaken. Identifying 
the Gambierdiscus species and toxins responsible for CFP in Australia is a critical first step toward improving risk management strategies and helping safeguard consumers and the seafood industry. In this study, we established 14 strains of Gambierdiscus from eastern Australia, identifying four Gambierdiscus species at a tropical site, two of which could represent new species, and one species at a temperate site. Using a functional bioassay approach, we demonstrated that extracts of G. lapillus and two other Gambierdiscus species (Gambierdiscus sp., UTSHI6A6 and UTSHI6B1) show CTX-like activities. Furthermore, based on the LC-MS/MS results, we verified that this activity is not due to CTXs for which we have standards and that are usually tested for in Gambierdiscus extracts (P-CTX-3C, P-CTX-3B, P-CTX-4A, P-CTX-4B).

In this study, we uncovered considerable diversity of Gambierdiscus at the tropical site, recording four co-occurring species from Heron Island, Queensland. G. carpenteri was the only species found to occur at both the tropical and temperate locations (Merimbula, New South Wales). This species is one of the most widely distributed in the genus, occurring in the North Atlantic Ocean [37,60], North Pacific Ocean [13,36-38,61,62], South Pacific Ocean [60] and the Caribbean Sea [37,38]. In Australia, G. carpenteri has previously been documented in the central Great Barrier Reef in Townsville, Queensland [55,56], and at Merimbula and Wapengo Lagoon, New South Wales [57]. Our results, therefore verify earlier reports of G. carpenteri from tropical and temperate Australia.

Gambierdiscus lapillus was also identified from the tropical site. It was described by Kretzschmar et al. [58] from the same collection site at Heron Island and is currently the only other record of this species. However, increased sampling and identification of Gambierdiscus species will likely reveal a much larger distribution. Two additional strains of Gambierdiscus established in this study (Gambierdiscus sp.) were not genetically identical to other currently described species within the genus. These may represent additional undescribed species from Heron Island, although further morphological and molecular identifications are required to verify this. A recently described species of Gambierdiscus (G. honu) [40], has a wide distribution across the South Pacific Ocean, including Heron Island [15], but this species was not isolated in our study. This result highlights that a single sample collection and subsequent isolation process does not necessarily reveal all the diversity of a genus at a specific location.

The LC-MS/MS analyses did not detect any characterized microalgal CTXs (P-CTX-3C, P-CTX-3B, P-CTX-4A and P-CTX-4B) in any of the culture extracts. However, CTX-like activity was identified in three of the four species tested. Previous studies of the toxicology of Gambierdiscus from Australia are consistent with these results (Table 1). Using the same LC-MS/MS method, Kretzschmar et al. [58] did not detect characterized microalgal CTXs in strains of G. lapillus isolated from Heron Island but noted the presence of unassigned peaks in the CTX transition zone. Similarly, Kohli et al. [57] did not detect characterized microalgal CTXs in a collection of G. carpenteri cells taken directly from the field at Merimbula. The LC-MS/MS method used in these studies was targeted toward the identification of P-CTX-3C, P-CTX-3B, P-CTX-4A and P-CTX-4B only, as these are the currently characterized forms of microalgal origin for which standards are available. Structurally related compounds with different masses are therefore not recognised. This indicates that the CTX-like activity detected using the functional assay in our study, is likely caused by compounds which differ from the currently characterized CTXs of microalgal origin.

Gambierdiscus sp. (UTSHI6A6) produced the most distinct CTX-activity peak eluting at approximately $72 \mathrm{~min}$. In a study using the same cell-based functional assay, Lewis et al. [38] identified CTX-like activity which eluted at the same time in strains of G. ruetzleri (now Fukuyoa ruetzleri), G. carolinianus and G. ribotype 2. However, LC-MS/MS analyses have not been performed on the strains from Lewis et al. [38], so it is not known whether this activity is linked with known CTX congeners. The results from our study suggest that this may be a novel type of lipophilic toxin with CTX-like activity and its characterization should be the target of future research. Both strains of G. lapillus also showed CTX-like activity, although the elution time of the active fractions differed 
between strains. These differences may arise from strains producing different congeners of a toxin; however, understanding the reasons for such differences require further investigation.

Gambierdiscus sp. (UTSHI6B1) showed distinct CTX-like activity in a low polarity fraction collected at approximately $29 \mathrm{~min}$ from the dichloromethane phase where lipophilic compounds like CTXs accumulate. Known ciguatera toxins however, typically have higher polarities, so further research is needed to accurately classify this active fraction. G. carpenteri strains from tropical and temperate Australia did not show any distinct CTX-like activities, consistent with Lewis et al. [38] who tested two strains of G. carpenteri (originally isolated from Belize in the Caribbean Sea and Hawaii in the eastern North Pacific Ocean), using the same functional cell-based $\mathrm{Ca}^{2+}$ influx FLIPR bioassay. These results suggest that $G$. carpenteri does not produce detectable quantities of ciguatera causing sodium channel activation compounds and therefore, may not contribute to the occurrence of CFP.

Many Gambierdiscus species display toxicity in the lipophilic phase, following partitioning in assays such as the mouse bioassay and the mammalian cell-based neuroblastoma (N2a) assay, suggesting that CTXs or compounds with the same mode of action are present [16,36]. Efforts should be focused on testing whether the toxicity of these strains can be attributed to the CTXs characterized from French Polynesia, or whether toxins responsible for CFP differ between locations, as our findings seem to suggest. Certainly, our results suggest the CTX-like toxins from Australia may differ from those found in French Polynesia. CTXs isolated from marine fish also differ in structure from the CTXs produced by Gambierdiscus species, a result of bioaccumulation and biomagnification; however, the differences in the CTXs isolated from marine fish originating from different locations could suggest that the precursor toxins produced by Gambierdiscus sp. are just as diverse.

Large MTX-like activities were identified in the dichloromethane phase of all Gambierdiscus cell extracts, except for one strain of G. carpenteri isolated from temperate Australia. This was unexpected, as MTXs should only be present in the methanol phase following liquid partitioning of the microalgal cell extracts. However, the elution time of the MTX-like activity peak in the dichloromethane phase corresponds to a fraction with strong MTX-like activity in the methanol phase and therefore, likely represents a carryover of MTXs. Although liquid partitioning of lipophilic (CTX) and hydrophilic (MTX) compounds in cell extracts using dichloromethane and aqueous methanol is effective, some MTX carryover can occur. This was also observed at the same elution time in the original $\mathrm{Ca}^{2+}$ influx SH-SY5Y cell FLIPR bioassay method description by Lewis et al. [38]. CTX-like activity was also detected on the shoulders of this MTX-like activity. This is likely a result of sensitization of the sodium channels on the mammalian cell membrane in response to the addition of veratridine, resulting in a CTX-like activity peak and therefore, was not interpreted as an indicator of the presence of potential CTXs in this study. The MTX peak was not detected in G. carpenteri strain UTSMER9A3; however, CTX-like activity was. This was likely due to a lower level of MTX carryover from the methanol phase, only high enough to show a response after the addition of veratridine.

Yasumoto et al. [11] were the first to establish the link between CFP and the dinoflagellate Gambierdiscus. The structure of the microalgal derived CTXs responsible were later elucidated from a strain (RG1-1) of Gambierdiscus (reported as G. toxicus but taxonomic identity is uncertain) isolated from the Gambier Islands in French Polynesia [29,63-66]. Chinain et al. [23] then went on to complete the first comprehensive characterization of CTXs from two highly toxic strains of G. polynesiensis (TB-92 and RG-92) from French Polynesia, and the toxins characterized in these studies remain the primary toxins linked with CFP today.

G. polynesiensis has been consistently found to exhibit considerable CTX-like activity (receptor binding assay [23]; mouse bioassay [39]; neuro-2a Assay [67]) and is the only species shown to produce the characterized CTXs when tested using LC-MS/MS analyses [23,39]. G. polynesiensis is therefore thought to be an important contributor to CFP in the Pacific. Interestingly, a strain of G. polynesiensis was recently isolated and found not to produce CTXs when tested with LC-MS/MS, but this is highly unusual for this species [68]. Presently, only six strains of G. polynesiensis have been characterized in the literature, four from French Polynesia [23], one from the Cook Islands [39] and one from the 
Kermadec Islands [68]. These locations are all situated within the central South Pacific Ocean but CFP occurs across a much larger area (see review by Friedman et al. [3]), and CTXs are confirmed to be present in fish from many locations [69-72]. Therefore, either the distribution of G. polynesiensis is much larger than presently acknowledged, or there are other currently unidentified precursor toxins that contribute to CFP in other locations.

Four congeners of MTX have been described, MTX-1, MTX-2, MTX-3 and MTX-4 [30,73,74] and chemical detection methods exist for the two disulphated forms, MTX-1 and MTX-3. Using LC-MS/MS analyses, we did not detect MTX-1 in any of the strains isolated in this study. This structural form of MTX-1 was originally described from a strain of Gambierdiscus (FP) isolated from French Polynesia [73]. The species used for this original description is not known but MTX-1 has since only been identified in strains of G. australes from the Cook Islands [39], the Kermadec Islands [68,75] and Japan [74].

MTX-3 is a putative MTX first described by Holmes and Lewis [30]. It is structurally smaller than MTX-1 and MTX-2 but its complete structure, potency and mode of action remain unknown. Since the original description, MTX-3 has been found in all Gambierdiscus strains tested (T. Harwood pers comm), except for the temperate G. carpenteri strains isolated in this study [76]. The factors driving the differences in MTX-3 production between the tropical and temperate populations of G. carpenteri are unknown; however, our study shows that temperature is not one of them. MTX-4 is a recently described congener of MTX, found only to be present in strains of G. excentricus isolated from a variety of locations and is highly potent [74].

The $\mathrm{Ca}^{2+}$ influx SH-SY5Y cell FLIPR bioassay [38], showed that all strains of Gambierdiscus isolated from eastern Australia produce between two and four peaks displaying MTX-like activities. As LC-MS/MS analyses did not detect the presence of MTX-1 in these strains, the toxicity must therefore be attributed to other types of MTX. Pisapia et al. [74] tested a wide range of Gambierdiscus strains for the presence of the newly described toxin MTX-4 and found only G. excentricus produced this compound. It is therefore unlikely that the MTX-like activity in the strains tested in this study is related to the presence of MTX-4. Alternatively, MTX-2 was originally described from a strain of Gambierdiscus (NQ1) isolated from the central Great Barrier Reef, Australia [73]. As there is no chemical detection method for this congener of MTX, it is not known if any of the MTX-like activity peaks in this study are from MTX-2, however it is likely as the original description was based on strains originating from Australia.

MTXs are hydrophilic compounds and the likelihood of their contribution to human illness events was originally discarded due to their water solubility [72]. However, recent work has confirmed that MTXs can be retained in the viscera, liver and flesh of fish [77]. These recent findings, coupled with the consistent detection of MTX-like activity in all Gambierdiscus strains tested in this study and by others using functional assays (e.g., haemolytic activity [36,37], mouse bioassay $[19,59]$ and the $\mathrm{Ca}^{2+}$ influx SH-SY5Y cell FLIPR bioassay [38]), as well as the extremely high potency of these toxins, represent compelling arguments toward the need for further investigations into the role of MTXs in CFP.

\section{Materials and Methods}

\subsection{Sampling and Isolation}

Epiphytes, including associated benthic microalgae, were removed from the surface of seagrass (Zostera sp.) collected from the Merimbula Inlet, New South Wales, Australia (36.8979 $\left.{ }^{\circ} \mathrm{S}, 149.9044^{\circ} \mathrm{E}\right)$ and macroalgae (Padina sp., Laurencia sp. and Chnoospora sp.) collected from the Heron Island lagoon, Queensland, Australia (23.4423 S, 151.9148 ${ }^{\circ}$ E) on 7 April 2014 (austral autumn) and 27 July 2014 (austral winter), respectively.

Single cells of Gambierdiscus spp. were isolated using the micropipette technique [78] and placed in individual wells of a 48 -well clear microplate with $0.2 \mu \mathrm{m}$ filtered sterilised and autoclaved seawater collected from each site and incubated in a plant growth chamber (Labec, Sydney, NSW, Australia) at $20{ }^{\circ} \mathrm{C}$ under $\sim 100 \mu \mathrm{mol}$ photons $\mathrm{m}^{-2} \mathrm{~s}^{-1}$ on a 12:12 light:dark cycle. Modified $\mathrm{K}$ medium [13] 
was gradually introduced as cells began to grow (i.e., 1:10 v/v, then increasing quantities until 1:1). Once isolates reached a concentration of approximately 20 cells per well, each was transferred to $25 \mathrm{~cm}^{2}$ (50 mL) sterile vented polystyrene tissue culture flasks (Falcon, Corning, NY, USA), oriented horizontally. Established cultures were then maintained in these vessels in modified $\mathrm{K}$ medium made from sterile oceanic seawater (salinity was approximately $32 \mathrm{ppt}$ ), under $\sim 100 \mu \mathrm{mol}$ photons $\mathrm{m}^{-2} \mathrm{~s}^{-1}$ on a 12:12 light:dark cycle.

\subsection{Strain Identification}

Cells from approximately $100 \mathrm{~mL}$ of each Gambierdiscus culture were harvested by centrifugation at $600 \times g$ for $10 \mathrm{~min}$. DNA was extracted using a MoBio Soil DNA Extraction Kit following the manufacturer's instructions and sent to a commercial service (Australian Genomic Research Facility (AGRF), Queensland, Australia) where the D1-D3 region of the large subunit (LSU) rDNA was amplified using the primers D1R-F [79] and D3-R [80] and the D8-D10 region amplified using the primers D8F and D10R [13]. These genetic markers were selected because they are commonly used for the Gambierdiscus genus and many sequences are publicly available for comparison. PCR amplifications were carried out in $50 \mu \mathrm{L}$ reaction volumes containing AmpliTaq Gold 360 master mix, both forward and reverse primers $(2.5 \mu \mathrm{m})$ and template at a concentration of $1 \mathrm{ng} \mu \mathrm{L}^{-1}$. Thermocycling conditions for the D1-D3 region were $95^{\circ} \mathrm{C}$ for $5 \mathrm{~min}, 35$ cycles at $95^{\circ} \mathrm{C}$ for $30 \mathrm{~s}, 60^{\circ} \mathrm{C}$ for $2 \mathrm{~min}$, with a final step at $72{ }^{\circ} \mathrm{C}$ for $10 \mathrm{~min}$. Thermocycling conditions for the D8-D10 region were $95^{\circ} \mathrm{C}$ for $5 \mathrm{~min}, 35$ cycles at $95^{\circ} \mathrm{C}$ for $30 \mathrm{~s}, 54{ }^{\circ} \mathrm{C}$ for $30 \mathrm{~s}, 72^{\circ} \mathrm{C}$ for $1 \mathrm{~min}$, with a final step at $72{ }^{\circ} \mathrm{C}$ for $5 \mathrm{~min}$. Amplification products ( $~ 950 \mathrm{bp}$ ) were purified and sequenced in both directions using the Sanger sequencing platform.

Phylogenetic analyses were conducted in Genious v9.1.5 [81]. Publicly available sequences of Gambierdiscus spp. and sequences used as out-groups (Akashiwo sanguinea, Prorocentrum micans and Alexandrium affine, A. catenella and A. tamarense) were downloaded from GenBank (www.ncbi.nlm.nih. gov) and aligned with the sequences obtained from this study, using the MUSCLE algorithm (maximum number of iterations 8) [82]. Sequences from the D1-D3 and D8-D10 regions were truncated to 979 bp and $764 \mathrm{bp}$, respectively. Maximum Likelihood (ML) phylogenetic trees were generated for both regions with PHYML with 1000 bootstraps [83] using a GTR substitution model and an estimated gamma distribution. Bayesian analysis was performed for both regions using MrBayes 3.2.6 [84] by means of the GTR+G (general-time reversible with gamma-shaped among-site variation) model. Bayesian analyses were carried out in four simultaneous runs with four chains each for $3.1 \times 10^{6}$ generations, sampling every 1000 trees and 1000 trees were discarded as burn in.

\subsection{Toxicology}

4.3.1. Detecting P-CTX-3B, P-CTX-3C, P-CTX-4A and P-CTX-4B Using Liquid Chromatography-Tandem Mass Spectrometry (LC-MS/MS)

To test for the presence of CTXs commonly linked with CFP (P-CTX-3B, P-CTX-3C, P-CTX-4A, P-CTX-4B), Gambierdiscus strains isolated in this study were cultured in triplicate $75 \mathrm{~cm}^{2}$ (250 mL) sterile vented polystyrene tissue culture flasks (Falcon, Corning, NY, USA), at $24{ }^{\circ} \mathrm{C}$ in a temperature-controlled room under the maintenance conditions described above. To test the effect of temperature on toxin production by the tropical and temperate strains of G. carpenteri, an experiment was performed where cultures of the tropical and temperate strains (UTSHI2C4 and UTSMER9A3, respectively) were grown at 18 or $27^{\circ} \mathrm{C}$ in temperature-controlled plant growth cabinets (Climatron ${ }^{\circledR}$, Plant Growth Cabinet, Australia).

Cell growth was monitored using in vivo chlorophyll $a$ fluorescence measurements. A $1 \mathrm{~mL}$ aliquot was taken every 3 to 4 days from each flask and in vivo chlorophyll $a$ fluorescence was measured for each sample using a fluorometer (Turner Designs, Trilogy ${ }^{\circledR}$, San Jose, CA, USA) and then preserved with $1 \%$ Lugols iodine solution. Cultures were harvested in early stationary phase by 
centrifugation $(3000 \times g$ for $10 \mathrm{~min}$ ) and the three replicates were pooled to yield sufficient biomass before being freeze dried until further LC-MS/MS analyses.

Lugols-preserved cells were used to estimate the number of cells in each cell pellet. The final $1 \mathrm{~mL}$ aliquot of culture collected prior to harvesting was counted using a Sedgewick Rafter Counting Chamber under an inverted light microscope $(\times 100$ magnification) (Nikon Instruments, Nikon Eclipse TS100, Melville, NY, USA).

Analysis of selected CTXs was carried out using a quantitative LC-MS/MS method developed at the Cawthron Institute (full method details will be disclosed in an upcoming manuscript by T. Harwood). Microalgal pellets containing between $2.0 \times 10^{5}$ and $2.0 \times 10^{6}$ cells were extracted in $1 \mathrm{~mL}$ of $100 \% \mathrm{MeOH}$ in glass tubes, then mixed and sonicated for $5 \mathrm{~min}$. Samples were transferred to glass auto sampler vials using a glass pipette and $2 \mu \mathrm{L}$ was injected for analysis. LC-MS/MS analysis was performed on an Ultra Performance Liquid Chromatography (UPLC) coupled to a mass spectrometer with electrospray ionization. Chromatographic separation used a BEH Phenyl column eluted with ammoniated mobile phases; (A) Milli-Q and (B) acetonitrile. Starting conditions were $25 \%$ B followed by a stepped gradient to $95 \%$ B after $8 \mathrm{~min}$, with re-equilibration to $25 \%$ B between 8 and $9 \mathrm{~min}$. A flow rate $0.55 \mathrm{~mL} \mathrm{~min}^{-1}$ was used and the total run time was $9 \mathrm{~min}$. Microalgal CTX reference material (P-CTX-3B; P-CTX-3C; P-CTX-4A; P-CTX-4B) was supplied by Institut Louis Malardé, French Polynesia.

MTX-1 (limit of detection of $1 \mathrm{ng} \mathrm{mL}{ }^{-1}$ ) and putative MTX-3 were monitored as intact structures using methods developed at Cawthron Institute $[85,86]$. Briefly, for MTX-1, a pseudo multiple reaction monitoring $(\mathrm{MRM})$ transition $(m / z 1689.6>1689.6)$ was acquired for the intact di-anion with the electrospray ionization source being operated in negative-ion mode. It was also possible to monitor the presence of the sulphated polyether analyte known as MTX-3 using a specific MRM transition $(m / z 1037.6>96.8)$.

\subsubsection{Ciguatoxin (CTX) and Maitotoxin-Like (MTX) Activities}

Selected strains of Gambierdiscus (tropical G. carpenteri UTSHI2C4, UTSHI6C3; temperate G. carpenteri UTSMER8B4, UTSMER9A3; G. lapillus UTSHI6B5, UTSHI2B6; Gambierdiscus sp. UTSHI6A6; Gambierdiscus sp. UTSHI6B1) were analysed for CTX and MTX-like activities. Strains were grown under standard conditions at $24^{\circ} \mathrm{C}$ in a temperature-controlled room in $2 \times 2 \mathrm{~L}$ glass Schott bottles. Chlorophyll $a$ in vivo fluorescence was used as a proxy for cell abundance to track growth and duplicate bottles were pooled and harvested in the early stationary phase by first concentrating the cells on a $20 \mu \mathrm{m}$ sieve, followed by centrifugation (3000 $\times \mathrm{g}$ for $10 \mathrm{~min}$ ). Total cell abundances ranged between $1.0 \times 10^{6}$ and $3.5 \times 10^{6}$.

CTX and MTX-like activities were determined following the functional bioassay described by Lewis et al. [38]. Briefly, cell pellets were extracted twice in a mix of analytical grade methanol:ultrapure water:hexane (2:1:1) at a concentration of $10 \mathrm{~mL}$ per $1.0 \times 10^{6}$ cells and subsequently sonicated twice for 1 min using a sonication probe (QSonica) at an amplitude of 50\%. The extract was then centrifuged to remove cell debris $(600 \times g$ for $10 \mathrm{~min})$ and the supernatant layers sampled. The hexane layer was discarded and the remaining extract dried under $\mathrm{N}_{2}$ gas, then reconstituted in $10 \mathrm{~mL}$ dichloromethane (DCM) and extracted twice with $5 \mathrm{~mL} \mathrm{60 \%} \mathrm{methanol} \mathrm{(MeOH).} \mathrm{The} \mathrm{DCM} \mathrm{lipophilic} \mathrm{phase} \mathrm{containing}$ CTXs (top layer) was then separated from the $\mathrm{MeOH}$ hydrophilic phase containing MTXs (bottom layer) and each phase was dried separately under $\mathrm{N}_{2}$ gas in $20 \mathrm{~mL}$ amber glass vials.

The dried extracts were reconstituted in $30 \%$ acetonitrile $(\mathrm{ACN}) / 0.1 \%$ formic acid (FA) and approximately $1.0 \times 10^{6}$ microalgal cell equivalents were used for fractionation. Extracts were fractionated on an UltiMate 3000 Rapid Separation Liquid Chromatography System (Dionex, IL, USA) with a FC 204 Fraction Collector (Gilson, Middleton, WI, USA). Grace Vydac C18 (218TP) Reverse-Phase HPLC Column $(250 \times 4.6 \mathrm{~mm}, 5 \mu \mathrm{m})$ (Grace Hichrom, Berkshire, UK) was used to separate the extracts with $0.043 \%$ trifluoroacetic acid $/ 90 \%$ acetonitrile (aq) as elution buffer B and $0.05 \%$ trifluoroacetic acid (aq) as buffer A. Initial elution was at $5 \%$ B for $5 \mathrm{~min}$ and then increased 
linearly to $90 \% \mathrm{~B}$ over $60 \mathrm{~min}$ at a flow rate of $0.7 \mathrm{~mL} \mathrm{~min}{ }^{-1}$. 77 fractions were collected, freeze dried and reconstituted in $30 \mu \mathrm{L}$ physiological salt solution (PSS; composition $\mathrm{NaCl} 140 \mathrm{mM}$, glucose $11.5 \mathrm{mM}, \mathrm{KCl} 5.9 \mathrm{mM}, \mathrm{MgCl}_{2} 1.4 \mathrm{mM}, \mathrm{NaH}_{2} \mathrm{PO}_{4} 1.2 \mathrm{mM}, \mathrm{NaHCO}_{3} 5 \mathrm{mM}, \mathrm{CaCl} 21.8 \mathrm{mM}, \mathrm{HEPES}$ $10 \mathrm{mM}$ ) containing $0.1 \%$ bovine serum albumin (BSA) just prior to $\mathrm{Ca}^{2+}$ influx SH-SY5Y cell FLIPR bioassay analysis.

Functional activity of extracts was then determined following Lewis et al. [38]. Briefly, SH-SY5Y human neuronal cells (ECACC, Salisbury, Wiltshire, UK) were maintained in Roswell Park Memorial Institute (RPMI) media containing 15\% Foetal Bovine Serum (FBS) and $2 \mathrm{mM}$ L-glutamine, 100 units $\mathrm{mL}^{-1}$ penicillin and $0.1 \mathrm{mg} \mathrm{L}^{-1}$ streptomycin at $37^{\circ} \mathrm{C}$, under $5 \% \mathrm{CO}_{2}$ atmosphere. Cells were routinely split once a week at a 1:5 dilution using $0.25 \%$ trypsin with ethylenediaminetetraacetic acid (EDTA) (Gibco).

For the $\mathrm{Ca}^{2+}$ influx FLIPR bioassay, SH-SY5Y cells were planted into 384-well black walled imaging plates (Corning, Australia) at a density of 50,000 cells per well and cultured for 48 h. Fluorescent responses (excitation, 470-495 $\mathrm{nm}$; emission, 515-575 $\mathrm{nm}$ ) were assessed using the FLIPR ${ }^{\text {TETRA }}$ Fluorescent Imaging Plate Reader (Molecular Devices, Sunnydale, CA, USA) after a 30 min incubation with a fluorescent $\mathrm{Ca}^{2+}$ dye (Calcium 4 No Wash Dye, Molecular Devices) diluted in PSS containing $0.1 \%$ BSA. Ten microliters of reconstituted HPLC fractions were added to each well and the fluorescence response recorded for $5 \mathrm{~min}$ prior to stimulation with $5 \mu \mathrm{M}$ veratridine. Signals were interpreted as follows: If MTX-like activity was detected in the sample, calcium influx would be evident in this early stage of the assay. If a second peak was detected in response to veratridine addition, this was interpreted as an effect of CTX-like activity which acts to enhance an otherwise sub-effective dose of veratridine. Positive control standards of P-CTX-2 and P-CTX-3 were used to verify CTX-like activity. The assay detected P-CTX-2 at $9.51 \pm 0.13$ and P-CTX-3 at $9.26 \pm 0.14,\left(\mathrm{pEC}_{50}, n=2\right)$ in the presence of $5 \mu \mathrm{m}$ veratridine, consistent with previous results using this assay by Lewis et al. [38].

FLIPR assay data were analysed using ScreenWorks 3.2.0.1.4 (Molecular Devices, Sunnydale, CA, USA). For each fraction, the MTX-like activity was normalized to the baseline and the maximum peak height in the following 300 reads represented the MTX-like response. CTX-like activity was normalized to the veratridine response and the maximum peak height after the veratridine addition represented the CTX-like response.

\section{Conclusions}

In this study, 14 strains of Gambierdiscus were established from eastern Australia, representing four species. Extracts of three species showed CTX-like activity, likely caused by compounds which are distinct from currently characterized toxins. These results suggest that toxins produced by these Australian strains of Gambierdiscus likely differ from those currently linked with CFP identified in extracts of G. polynesiensis from French Polynesia, though characterization of the compounds responsible for the CTX-like activity is necessary to evaluate this. Although this study was limited to Australian strains of Gambierdiscus, the findings are likely universal and therefore, a concentrated effort should be made toward testing and characterizing the toxicology of strains from other locations. Future research should also include establishing a baseline of Gambierdiscus species distribution in Australia, understanding the relative abundance of each species and finding out how these organisms are influenced by environmental conditions, particularly in view of a changing climate.

Acknowledgments: We would like to acknowledge Samuel Avery for assistance with collecting epibenthic microalgal samples from Merimbula, New South Wales, Australia and Peter Ralph for collecting epibenthic microalgal samples from Heron Island, Queensland, Australia. We thank Tim Kahlke for assistance with phylogenetic analyses and the Institute of Molecular Biosciences at the University of Queensland for use of their facilities for the FLIPR analyses. We also want to acknowledge Sam Murray from the Cawthron Institute, New Zealand for his help with some of the LC-MS/MS analyses. This research was supported by funding from the PADI Foundation (M.E.L.) and the Estuarine and Coastal Sciences Association (ECSA) (M.E.L.). M.E.L. is supported by an Australian Government Training Program Scholarship, R.J.L. by a National Health Medical Research Council (NHMRC) Principal Research Fellowship, S.W.A.H. by a University of Queensland Postdoctoral 
Fellowship, O.F.L. by a University of Technology Sydney Chancellor's Postdoctoral Fellowship and S.A.M. is an Australian Research Council (ARC) Future Fellow.

Author Contributions: M.E.L. conceived the idea, isolated, established and maintained all microalgal cultures, carried out DNA extractions, experimental work, data analysis, designed the study and drafted the manuscript; O.F.L., S.A.M. and M.A.D. participated in the design of the study and helped draft the manuscript. D.T.H. performed the LC-MS/MS toxin analyses. R.J.L. and S.W.A.H. provided access to the facilities and assisted with the FLIPR assays. All authors contributed to and edited drafts of the manuscript.

Conflicts of Interest: The authors declare no conflict of interest. The founding sponsors had no role in the design of the study; in the collection, analyses, or interpretation of data; in the writing of the manuscript and in the decision to publish the results.

\section{References}

1. Lehane, L.; Lewis, R.J. Ciguatera: Recent advances but the risk remains. Int. J. Food Microbiol. 2000, 61, 91-125. [CrossRef]

2. Dickey, R.W.; Plakas, S.M. Ciguatera: A public health perspective. Toxicon 2010, 56, 123-136. [CrossRef] [PubMed]

3. Friedman, M.A.; Fernandez, M.; Backer, L.C.; Dickey, R.W.; Bernstein, J.; Schrank, K.; Kibler, S.; Stephan, W.; Gribble, M.O.; Bienfang, P. An updated review of ciguatera fish poisoning: Clinical, epidemiological, environmental and public health management. Mar. Drugs 2017, 15, 72. [CrossRef] [PubMed]

4. Friedman, M.A.; Fleming, L.E.; Fernandez, M.; Bienfang, P.; Schrank, K.; Dickey, R.; Bottein, M.-Y.; Backer, L.; Ayyar, R.; Weisman, R. Ciguatera fish poisoning: Treatment, prevention and management. Mar. Drugs 2008, 6, 456-479. [CrossRef] [PubMed]

5. Bagnis, R.; Kuberski, T.; Laugier, S. Clinical observations on 3009 cases of ciguatera (fish poisoning) in the South Pacific. Am. J. Trop. Med. Hyg. 1979, 28, 1067-1073. [CrossRef] [PubMed]

6. Lewis, N.D. Epidemiology and impact of ciguatera in the Pacific: A review. Mar. Fish. Rev. 1986, 48, 6-13.

7. Skinner, M.P.; Brewer, T.D.; Johnstone, R.; Fleming, L.E.; Lewis, R.J. Ciguatera fish poisoning in the Pacific Islands (1998 to 2008). PLoS Negl. Trop. Dis. 2011, 5, e1416. [CrossRef] [PubMed]

8. De Haro, L.; Pommier, P.; Valli, M. Emergence of imported ciguatera in Europe: Report of 18 cases at the Poison Control Centre of Marseille. J. Toxicol. Clin. Toxicol. 2003, 41, 927-930. [CrossRef] [PubMed]

9. Mattei, C.; Vetter, I.; Eisenblätter, A.; Krock, B.; Ebbecke, M.; Desel, H.; Zimmermann, K. Ciguatera fish poisoning: A first epidemic in Germany highlights an increasing risk for European countries. Toxicon 2014, 91, 76-83. [CrossRef] [PubMed]

10. Zimmermann, K.; Eisenblätter, A.; Vetter, I.; Ebbecke, M.; Friedemann, M.; Desel, H. Imported tropical fish causes ciguatera fish poisoning in Germany. Deutsche Medizinische Wochenschrift (1946) 2015, 140, 125-130.

11. Yasumoto, T.; Nakajima, I.; Bagnis, R.; Adachi, R. Finding of a dinoflagellate as a likely culprit of ciguatera. Bull. Jpn. Soc. Sci. Fish. 1977, 43, 1021-1026. [CrossRef]

12. Adachi, R.; Fukuyo, Y. The thecal structure of a marine toxic dinoflagellate Gambierdiscus toxicus gen. et sp. nov. collected in a ciguatera-endemic area. Bull. Jpn. Soc. Sci. Fish. 1979, 45, 67-71. [CrossRef]

13. Litaker, R.W.; Vandersea, M.W.; Faust, M.A.; Kibler, S.R.; Chinain, M.; Holmes, M.J.; Holland, W.C.; Tester, P.A. Taxonomy of Gambierdiscus including four new species, Gambierdiscus caribaeus, Gambierdiscus carolinianus, Gambierdiscus carpenteri and Gambierdiscus ruetzleri (Gonyaulacales, Dinophyceae). Phycologia 2009, 48, 344-390. [CrossRef]

14. Nishimura, T.; Sato, S.; Tawong, W.; Sakanari, H.; Yamaguchi, H.; Adachi, M. Morphology of Gambierdiscus scabrosus sp. nov. (Gonyaulacales): A new epiphytic toxic dinoflagellate from coastal areas of Japan. J. Phycol. 2014, 50, 506-514. [CrossRef] [PubMed]

15. Richlen, M.L.; Morton, S.L.; Barber, P.H.; Lobel, P.S. Phylogeography, morphological variation and taxonomy of the toxic dinoflagellate Gambierdiscus toxicus (Dinophyceae). Harmful Algae 2008, 7, 614-629. [CrossRef]

16. Xu, Y.; Richlen, M.L.; Morton, S.L.; Mak, Y.L.; Chan, L.L.; Tekiau, A.; Anderson, D.M. Distribution, abundance and diversity of Gambierdiscus spp. from a ciguatera-endemic area in Marakei, Republic of Kiribati. Harmful Algae 2014, 34, 56-68. [CrossRef]

17. Fraga, S.; Rodríguez, F.; Caillaud, A.; Diogène, J.; Raho, N.; Zapata, M. Gambierdiscus excentricus sp. nov. (Dinophyceae), a benthic toxic dinoflagellate from the Canary Islands (NE Atlantic Ocean). Harmful Algae 2011, 11, 10-22. [CrossRef] 
18. Faust, M.A. Observation of sand-dwelling toxic dinoflagellates (Dinophyceae) from widely differing sites, including two new species. J. Phycol. 1995, 31, 996-1003. [CrossRef]

19. Chinain, M.; Faust, M.A.; Pauillac, S. Morphology and molecular analyses of three toxic species of Gambierdiscus (Dinophyceae): G. pacificus, sp. nov., G. australes, sp. nov. and G. polynesiensis, sp. nov. J. Phycol. 1999, 35, 1282-1296. [CrossRef]

20. Benoit, E.; Legrand, A.; Dubois, J. Effects of ciguatoxin on current and voltage clamped frog myelinated nerve fibre. Toxicon 1986, 24, 357-364. [CrossRef]

21. Legrand, A.; Litaudon, M.; Genthon, J.; Bagnis, R.; Yasumoto, T. Isolation and some properties of ciguatoxin. J. Appl. Phycol. 1989, 1, 183-188. [CrossRef]

22. Lombet, A.; Bidard, J.-N.; Lazdunski, M. Ciguatoxin and brevetoxins share a common receptor site on the neuronal voltage-dependent $\mathrm{Na}^{+}$channel. FEBS Lett. 1987, 219, 355-359. [CrossRef]

23. Chinain, M.; Darius, H.T.; Ung, A.; Cruchet, P.; Wang, Z.; Ponton, D.; Laurent, D.; Pauillac, S. Growth and toxin production in the ciguatera-causing dinoflagellate Gambierdiscus polynesiensis (Dinophyceae) in culture. Toxicon 2010, 56, 739-750. [CrossRef] [PubMed]

24. Yogi, K.; Sakugawa, S.; Oshiro, N.; Ikehara, T.; Sugiyama, K.; Yasumoto, T. Determination of toxins involved in ciguatera fish poisoning in the Pacific by LC/MS. J. AOAC Int. 2014, 97, 398-402. [CrossRef] [PubMed]

25. Yogi, K.; Oshiro, N.; Inafuku, Y.; Hirama, M.; Yasumoto, T. Detailed LC-MS/MS analysis of ciguatoxins revealing distinct regional and species characteristics in fish and causative alga from the Pacific. Anal. Chem. 2011, 83, 8886-8891. [CrossRef] [PubMed]

26. Hamilton, B.; Hurbungs, M.; Vernoux, J.-P.; Jones, A.; Lewis, R.J. Isolation and characterisation of Indian Ocean ciguatoxin. Toxicon 2002, 40, 685-693. [CrossRef]

27. Lewis, R.J.; Vernoux, J.-P.; Brereton, I.M. Structure of Caribbean ciguatoxin isolated from Caranx latus. J. Am. Chem. Soc. 1998, 120, 5914-5920. [CrossRef]

28. Lewis, R.J.; Sellin, M.; Poli, M.A.; Norton, R.S.; MacLeod, J.K.; Sheil, M.M. Purification and characterization of ciguatoxins from moray eel (Lycodontis javanicus, Muraenidae). Toxicon 1991, 29, 1115-1127. [CrossRef]

29. Murata, M.; Legrand, A.M.; Ishibashi, Y.; Yasumoto, T. Structures of ciguatoxin and its congener. J. Am. Chem. Soc. 1989, 111, 8929-8931. [CrossRef]

30. Holmes, M.J.; Lewis, R.J. Purification and characterisation of large and small maitotoxins from cultured Gambierdiscus toxicus. Natl. Toxins 1994, 2, 64-72. [CrossRef]

31. Gusovsky, F.; Daly, J.W. Maitotoxin: A unique pharmacological tool for research on calcium-dependent mechanisms. Biochem. Pharmacol. 1990, 39, 1633-1639. [CrossRef]

32. Murata, M.; Gusovsky, F.; Yasumoto, T.; Daly, J.W. Selective stimulation of $\mathrm{Ca}^{2+}$ flux in cells by maitotoxin. Eur. J. Pharmacol. Mol. Pharmacol. 1992, 227, 43-49. [CrossRef]

33. Trevino, C.; Escobar, L.; Vaca, L.; Morales-Tlalpan, V.; Ocampo, A.; Darszon, A. Maitotoxin: A Unique Pharmacological Tool for Elucidating $\mathrm{Ca}^{2+}$ Dependent Mechanisms. Food Sci. Technol. 2008, 173, 503.

34. Murata, M.; Naoki, H.; Iwashita, T.; Matsunaga, S.; Sasaki, M.; Yokoyama, A.; Yasumoto, T. Structure of maitotoxin. J. Am. Chem. Soc. 1993, 115, 2060-2062. [CrossRef]

35. Hoffman, P.A.; Granade, H.R.; McMillan, J.P. The mouse ciguatoxin bioassay: A dose-response curve and symptomatology analysis. Toxicon 1983, 21, 363-369. [CrossRef]

36. Pisapia, F.; Holland, W.C.; Hardison, D.R.; Litaker, R.W.; Fraga, S.; Nishimura, T.; Adachi, M.; Nguyen-Ngoc, L.; Séchet, V.; Amzil, Z. Toxicity screening of 13 Gambierdiscus strains using neuro-2a and erythrocyte lysis bioassays. Harmful Algae 2017, 63, 173-183. [CrossRef] [PubMed]

37. Holland, W.C.; Litaker, R.W.; Tomas, C.R.; Kibler, S.R.; Place, A.R.; Davenport, E.D.; Tester, P.A. Differences in the toxicity of six Gambierdiscus (Dinophyceae) species measured using an in vitro human erythrocyte lysis assay. Toxicon 2013, 65, 15-33. [CrossRef] [PubMed]

38. Lewis, R.J.; Inserra, M.; Vetter, I.; Holland, W.C.; Hardison, D.R.; Tester, P.A.; Litaker, R.W. Rapid extraction and identification of maitotoxin and ciguatoxin-like toxins from caribbean and pacific Gambierdiscus using a new functional bioassay. PLoS ONE 2016, 11, e0160006. [CrossRef] [PubMed]

39. Rhodes, L.; Harwood, T.; Smith, K.; Argyle, P.; Munday, R. Production of ciguatoxin and maitotoxin by strains of Gambierdiscus australes, G. pacificus and G. polynesiensis (Dinophyceae) isolated from Rarotonga, Cook Islands. Harmful Algae 2014, 39, 185-190. [CrossRef] 
40. Rhodes, L.; Smith, K.F.; Verma, A.; Curley, B.G.; Harwood, D.T.; Murray, S.; Kohli, G.S.; Solomona, D.; Rongo, T.; Munday, R. A new species of Gambierdiscus (Dinophyceae) from the south-west Pacific: Gambierdiscus honu sp. nov. Harmful Algae 2017, 65, 61-70. [CrossRef] [PubMed]

41. Smith, K.F.; Rhodes, L.; Verma, A.; Curley, B.G.; Harwood, D.T.; Kohli, G.S.; Solomona, D.; Rongo, T.; Munday, R.; Murray, S.A. A new Gambierdiscus species (Dinophyceae) from Rarotonga, Cook Islands: Gambierdiscus cheloniae sp. nov. Harmful Algae 2016, 60, 45-56. [CrossRef] [PubMed]

42. Gillespie, N.; Lewis, R.; Pearn, J.; Bourke, A.; Holmes, M.; Bourke, J.; Shields, W. Ciguatera in Australia. Occurrence, clinical features, pathophysiology and management. Med. J. Aust. 1985, 145, 584-590.

43. Hamilton, B.; Whittle, N.; Shaw, G.; Eaglesham, G.; Moore, M.R.; Lewis, R.J. Human fatality associated with Pacific ciguatoxin contaminated fish. Toxicon 2010, 56, 668-673. [CrossRef] [PubMed]

44. Clark, L.; Whitwell, G. Ciguatera poisoning in cats in Brisbane. Aust. Vet. J. 1968, 44, 81. [CrossRef] [PubMed]

45. Lewis, R.; Chaloupka, M.; Gillespie, N.; Holmes, M. An analysis of the human response to ciguatera in Australia. In Proceedings of the 6th International Coral Reef Symposium: Volume 3: Contributed Papers, Townsville, Australia; Choat, J.H., Barnes, D., Borowitzka, M.A., Coll, J.C., Davies, P.J., Flood, P., Hatcher, B.G., Hopley, D., Hutchings, P.A., Kinsey, D., et al., Eds.; International Society for Reef Studies: Townsville, Australia, 1988; pp. 67-72.

46. Lucas, R.E.; Lewis, R.J.; Taylor, J.M. Pacific Ciguatoxin-1 associated with a large common-source outbreak of Ciguatera in East Arnhem Land, Australia. Natl. Toxins 1997, 5, 136-140. [CrossRef]

47. Farrell, H.; Zammit, A.; Manning, J.; Shadbolt, C.; Szabo, L.; Harwood, D.T.; McNabb, P.; Turahui, J.A.; van den Berg, D.J. Clinical diagnosis and chemical confirmation of ciguatera fish poisoning in New South Wales, Australia. Commun. Dis. Intell. Q. Rep. 2016, 40, E1-E6. [PubMed]

48. Hallegraeff, G.M. A review of harmful algal blooms and their apparent global increase. Phycologia 1993, 32, 79-99. [CrossRef]

49. Holmes, M.J.; Lewis, R.J.; Poli, M.A.; Gillespie, N.C. Strain dependent production of ciguatoxin precursors (gambiertoxins) by Gambierdiscus toxicus (Dinophyceae) in culture. Toxicon 1991, 29, 761-775. [CrossRef]

50. Gillespie, N.; Holmes, M.; Burke, J.; Doley, J. Distribution and periodicity of Gambierdiscus toxicus in Queensland, Australia. In Toxic Dinoflagellates; Elsevier: New York, NY, USA, 1985; pp. 183-188.

51. Skinner, M.P.; Lewis, R.J.; Morton, S. Ecology of the ciguatera causing dinoflagellates from the Northern Great Barrier Reef: Changes in community distribution and coastal eutrophication. Mar. Pollut. Bull. 2013, 77, 210-219. [CrossRef] [PubMed]

52. Sparrow, L.; Heimann, K. Key Environmental Factors in the Management of Ciguatera. J. Coast. Res. 2016, 75, 1007-1011. [CrossRef]

53. Kohli, G.S.; Neilan, B.A.; Brown, M.V.; Hoppenrath, M.; Murray, S.A. Cob gene pyrosequencing enables characterization of benthic dinoflagellate diversity and biogeography. Environ. Microbiol. 2014, 16, 467-485. [CrossRef] [PubMed]

54. Ajani, P.; Brett, S.; Krogh, M.; Scanes, P.; Webster, G.; Armand, L. The risk of harmful algal blooms (HABs) in the oyster-growing estuaries of New South Wales, Australia. Environ. Monit. Assess. 2013, 185, 5295-5316. [CrossRef] [PubMed]

55. Murray, S.; Momigliano, P.; Heimann, K.; Blair, D. Molecular phylogenetics and morphology of Gambierdiscus yasumotoi from tropical eastern Australia. Harmful Algae 2014, 39, 242-252. [CrossRef]

56. Sparrow, L.; Momigliano, P.; Russ, G.R.; Heimann, K. Effects of temperature, salinity and composition of the dinoflagellate assemblage on the growth of Gambierdiscus carpenteri isolated from the Great Barrier Reef. Harmful Algae 2017, 65, 52-60. [CrossRef] [PubMed]

57. Kohli, G.S.; Murray, S.A.; Neilan, B.A.; Rhodes, L.L.; Harwood, D.T.; Smith, K.F.; Meyer, L.; Capper, A.; Brett, S.; Hallegraeff, G.M. High abundance of the potentially maitotoxic dinoflagellate Gambierdiscus carpenteri in temperate waters of New South Wales, Australia. Harmful Algae 2014, 39, 134-145. [CrossRef]

58. Kretzschmar, A.L.; Verma, A.; Harwood, T.; Hoppenrath, M.; Murray, S. Characterization of Gambierdiscus lapillus sp. nov. (Gonyaulacales, Dinophyceae): A new toxic dinoflagellate from the Great Barrier Reef (Australia). J. Phycol. 2017, 53, 283-297. [CrossRef] [PubMed]

59. Nishimura, T.; Sato, S.; Tawong, W.; Sakanari, H.; Uehara, K.; Shah, M.M.R.; Suda, S.; Yasumoto, T.; Taira, Y.; Yamaguchi, H. Genetic diversity and distribution of the ciguatera-causing dinoflagellate Gambierdiscus spp. (Dinophyceae) in coastal areas of Japan. PLoS ONE 2013, 8, e60882. [CrossRef] [PubMed] 
60. Lyu, Y.; Richlen, M.L.; Sehein, T.R.; Chinain, M.; Adachi, M.; Nishimura, T.; Xu, Y.; Parsons, M.L.; Smith, T.B.; Zheng, T. LSU rDNA based RFLP assays for the routine identification of Gambierdiscus species. Harmful Algae 2017, 66, 20-28. [CrossRef] [PubMed]

61. Kibler, S.R.; Litaker, R.W.; Holland, W.C.; Vandersea, M.W.; Tester, P.A. Growth of eight Gambierdiscus (Dinophyceae) species: Effects of temperature, salinity and irradiance. Harmful Algae 2012, 19, 1-14. [CrossRef]

62. Litaker, R.W.; Vandersea, M.W.; Faust, M.A.; Kibler, S.R.; Nau, A.W.; Holland, W.C.; Chinain, M.; Holmes, M.J.; Tester, P.A. Global distribution of ciguatera causing dinoflagellates in the genus Gambierdiscus. Toxicon 2010, 56, 711-730. [CrossRef] [PubMed]

63. Murata, M.; Legrand, A.M.; Ishibashi, Y.; Fukui, M.; Yasumoto, T. Structures and configurations of ciguatoxin from the moray eel Gymnothorax javanicus and its likely precursor from the dinoflagellate Gambierdiscus toxicus. J. Am. Chem. Soc. 1990, 112, 4380-4386. [CrossRef]

64. Satake, M.; Murata, M.; Yasumoto, T. The structure of CTX3C, a ciguatoxin congener isolated from cultured Gambierdiscus toxicus. Tetrahedron Lett. 1993, 34, 1975-1978. [CrossRef]

65. Satake, M.; MacKenzie, L.; Yasumoto, T. Identification of Protoceratium reticulatum as the biogenetic origin of yessotoxin. Natl. Toxins 1997, 5, 164-167. [CrossRef]

66. Yasumoto, T.; Igarashi, T.; Legrand, A.-M.; Cruchet, P.; Chinain, M.; Fujita, T.; Naoki, H. Structural elucidation of ciguatoxin congeners by fast-atom bombardment tandem mass spectroscopy. J. Am. Chem. Soc. 2000, 122, 4988-4989. [CrossRef]

67. Pawlowiez, R.; Darius, H.T.; Cruchet, P.; Rossi, F.; Caillaud, A.; Laurent, D.; Chinain, M. Evaluation of seafood toxicity in the Australes archipelago (French Polynesia) using the neuroblastoma cell-based assay. Food Addit. Contam. Part A 2013, 30, 567-586. [CrossRef] [PubMed]

68. Rhodes, L.L.; Smith, K.F.; Murray, S.; Harwood, D.T.; Trnski, T.; Munday, R. The epiphytic genus Gambierdiscus (Dinophyceae) in the Kermadec Islands and Zealandia regions of the southwestern Pacific and the associated risk of ciguatera fish poisoning. Mar. Drugs 2017, 15, 219. [CrossRef] [PubMed]

69. Bienfang, P.; Oben, B.; DeFelice, S.; Moeller, P.; Huncik, K.; Oben, P.; Toonen, R.; Daly-Engel, T.; Bowen, B. Ciguatera: The detection of neurotoxins in carnivorous reef fish from the coast of Cameroon, West Africa. Afr. J. Mar. Sci. 2008, 30, 533-540. [CrossRef]

70. Boada, L.D.; Zumbado, M.; Luzardo, O.P.; Almeida-González, M.; Plakas, S.M.; Granade, H.R.; Abraham, A.; Jester, E.L.; Dickey, R.W. Ciguatera fish poisoning on the West Africa Coast: An emerging risk in the Canary Islands (Spain). Toxicon 2010, 56, 1516-1519. [CrossRef] [PubMed]

71. Chinain, M.; Darius, H.T.; Ung, A.; Fouc, M.T.; Revel, T.; Cruchet, P.; Pauillac, S.; Laurent, D. Ciguatera risk management in French Polynesia: The case study of Raivavae Island (Australes Archipelago). Toxicon 2010, 56, 674-690. [CrossRef] [PubMed]

72. Lewis, R.J.; Holmes, M.J. Origin and transfer of toxins involved in ciguatera. Comp. Biochem. Physiol. Part C Pharmacol. Toxicol. Endocrinol. 1993, 106, 615-628. [CrossRef]

73. Holmes, M.J.; Lewis, R.J.; Gillespie, N.C. Toxicity of Australian and French Polynesian strains of Gambierdiscus toxicus (Dinophyceae) grown in culture: Characterization of a new type of maitotoxin. Toxicon 1990, 28, 1159-1172. [CrossRef]

74. Pisapia, F.; Sibat, M.; Herrenknecht, C.; Lhaute, K.; Gaiani, G.; Ferron, P.-J.; Fessard, V.; Fraga, S.; Nascimento, S.M.; Litaker, R.W. Maitotoxin-4, a Novel MTX Analog Produced by Gambierdiscus excentricus. Mar. Drugs 2017, 15, 220. [CrossRef] [PubMed]

75. Rhodes, L.L.; Smith, K.F.; Verma, A.; Murray, S.; Harwood, D.T.; Trnski, T. The dinoflagellate genera Gambierdiscus and Ostreopsis from subtropical Raoul Island and North Meyer Island, Kermadec Islands. N. Z. J. Mar. Freshw. Res. 2017, 51, 490-504. [CrossRef]

76. Munday, R.; Murray, S.; Rhodes, L.L.; Larsson, M.E.; Harwood, D.T. Ciguatoxins and Maitotoxins in Extracts of Sixteen Gambierdiscus Isolates and One Fukuyoa Isolate from the South Pacific and Their Toxicity to Mice by Intraperitoneal and Oral Administration. Mar. Drugs 2017, 15, 208. [CrossRef] [PubMed]

77. Kohli, G.S.; Papiol, G.G.; Rhodes, L.L.; Harwood, D.T.; Selwood, A.; Jerrett, A.; Murray, S.A.; Neilan, B.A. A feeding study to probe the uptake of Maitotoxin by snapper (Pagrus auratus). Harmful Algae 2014, 37, 125-132. [CrossRef] 
78. Andersen, R.A.; Kawachi, M. Traditional microalgae isolation techniques. In Algal Culturing Techniques; Andersen, R., Ed.; Phycological Society of America; Elsevier Academic Press: San Diego, CA, USA, 2005; Chapter 6; pp. 83-100.

79. Scholin, C.A.; Herzog, M.; Sogin, M.; Anderson, D.M. Identification of group-and strain-specific genetic markers for globally distributed Alexandrium (Dinophyceae). II. Sequence analysis of a fragment of the LSU rRNA gene. J. Phycol. 1994, 30, 999-1011. [CrossRef]

80. Nunn, G.; Theisen, B.; Christensen, B.; Arctander, P. Simplicity-correlated size growth of the nuclear $28 \mathrm{~S}$ ribosomal RNA D3 expansion segment in the crustacean order Isopoda. J. Mol. Evol. 1996, 42, 211-223. [CrossRef] [PubMed]

81. Kearse, M.; Moir, R.; Wilson, A.; Stones-Havas, S.; Cheung, M.; Sturrock, S.; Buxton, S.; Cooper, A.; Markowitz, S.; Duran, C. Geneious Basic: An integrated and extendable desktop software platform for the organization and analysis of sequence data. Bioinformatics 2012, 28, 1647-1649. [CrossRef] [PubMed]

82. Edgar, R.C. MUSCLE: Multiple sequence alignment with high accuracy and high throughput. Nucleic Acids Res. 2004, 32, 1792-1797. [CrossRef] [PubMed]

83. Guindon, S.; Gascuel, O. A simple, fast and accurate algorithm to estimate large phylogenies by maximum likelihood. Syst. Biol. 2003, 52, 696-704. [CrossRef] [PubMed]

84. Huelsenbeck, J.P.; Ronquist, F. MRBAYES: Bayesian inference of phylogenetic trees. Bioinformatics 2001, 17, 754-755. [CrossRef] [PubMed]

85. Selwood, A.; Rhodes, L.; Smith, K.; Harwood, D.T. Development of two novel UPLC-MS/MS methods for the analysis of maitotoxin from micro-algal cultures. In Marine and Freshwater Harmful Algae, Proceedings of the 16th International Conference on Harmful Algae, Wellington, New Zealand, 27-31 October 2014; Mackenzie, L., Ed.; International Society for the Study of Harmful Algae; Cawthron Institute: Nelson, New Zealand, 2015; p. 66.

86. Argyle, P.; Harwood, D.; Rhodes, L.; Champeau, O.; Tremblay, L. Toxicity assessment of New Zealand and Pacific dinoflagellates Ostreopsis and Gambierdiscus (Dinophyceae) extracts using bioassays. N. Z. J. Mar. Freshw. Res. 2016, 50, 444-456. [CrossRef] 